\title{
Obstructive sleep apnea prevents the expected difference in craniofacial growth of boys and girls
}

\author{
A apneia obstrutiva do sono impede a esperada diferença de crescimento cranofacial de \\ meninos e meninas
}

Maria Ligia Juliano', Marco Antonio Cardoso Machado², Luciane Bizari Coin de Carvalho³, Gianni Mara Silva dos Santos ${ }^{4}$, Edilson Zancanella ${ }^{5}$, Lucila Bizari Fernandes do Prado ${ }^{6}$, Gilmar Fernandes do Prado

\begin{abstract}
Objectives: It was to compare cephalometric measures of mouth-breather boys and girls and with the cephalometric pattern observed in obstructive sleep apnea syndrome (OSAS) patients. Methods: Craniofacial measurements of lateral cephalometric radiographs obtained from 144 children aged 7-14 years were compared between boys and girls, and both were compared to cephalometric pattern of OSAS patients. Results: Mouth-breather boys and girls had no gender differences regarding to craniofacial morphology while nose-breather boys and girls showed those expected differences. Nose-breather boys presented a more retruded mandible and proinclined upper incisor when compared to nose-breather girls, but mouth-breather boys and girls had no differences. The measure NS.GoGn was the only variable with an interaction with gender and breathing. Conclusions: There were no cephalometric difference in mouth breather-boys and girls related to normal growth, suggesting that oral breathing make the same craniofacial morphology and both have craniofacial morphology close to that of OSAS patients.
\end{abstract}

Key words: sleep apnea syndromes, mouth breathing, child, sleep apnea, obstructive, gender identity.

\section{RESUMO}

Objetivos: Foi comparar medidas cefalométricas entre meninos e meninas respiradores bucais com o padrão cefalométrico de pacientes com síndrome da apneia obstrutiva do sono (SAOS). Métodos: Medidas craniofaciais de radiografias cefalométricas laterais de 144 crianças com idade entre 7 e 14 anos foram comparadas entre meninos e meninas, e estas comparadas com o padrão cefalométrico de pacientes com SAOS. Resultados: Meninos e meninas respiradores bucais não apresentaram diferenças em relação à morfologia craniofacial, enquanto meninos e meninas respiradores nasais mostraram as diferenças fisiologicamente esperadas. Meninos respiradores nasais apresentaram mandíbula mais retraída e incisivos superiores inclinados para frente quando comparados com meninas respiradoras nasais, mas os respiradores bucais não apresentaram diferenças. A medida NS.GoGn foi a única variável com interação entre gênero e tipo de respiração. Conclusões: Não houve diferença cefalométrica entre os respiradores bucais em relação ao crescimento craniofacial, sugerindo que a respiração bucal determina a mesma morfologia, e ambos os gêneros têm morfologia craniofacial semelhante àquela dos pacientes com SAOS.

Palavras-Chave: síndromes da apnéia do sono, respiração bucal, criança, síndrome da apneia obstrutiva do sono, identidade de gênero.

${ }^{1}$ DDS, PhD, Orthodontist, Neuro-Sono researcher, Department of Neurology, São Paulo Hospital, Sleep Laboratory, Universidade Federal de Sào Paulo (UNIFESP), São Paulo SP, Brazil;

${ }^{2}$ DDS, PhD, Neuro-Sono researcher, Department of Neurology, São Paulo Hospital, Sleep Laboratory, UNIFESP, São Paulo SP, Brazil;

${ }^{3} \mathrm{PhD}$, Neuro-Sono researcher, Department of Neurology, São Paulo Hospital, Sleep Laboratory, UNIFESP, São Paulo SP, Brazil;

4Statistician, Neuro-Sono Section, Department of Neurology, São Paulo Hospital, Sleep Laboratory, UNIFESP, São Paulo SP, Brazil;

${ }^{5} \mathrm{MD}$, Otorhinolaryngologist, Neuro-Sono researcher, Neuro-Sono Section, Department of Neurology, São Paulo Hospital, Sleep Laboratory, UNIFESP, São Paulo SP, Brazil;

${ }^{6} \mathrm{MD}$, PhD, Co-Director of Neuro-Sono, Department of Neurology, São Paulo Hospital, Sleep Laboratory, UNIFESP, São Paulo SP, Brazil;

${ }^{7} \mathrm{MD}$, PhD Director of Neuro-Sono, Department of Neurology, São Paulo Hospital, Sleep Laboratory, UNIFESP, São Paulo SP, Brazil.

Correspondence: Luciane Bizari Coin de Carvalho; Rua Apeninos 930 / conj. 183;04104-020 São Paulo SP - Brasil; E-mail: lucianebizari@yahoo.com

Conflict of interest: There is no conflict of interest to declare.

Received 17 April 2012; Received in final form 23 August 2012; Accepted 31 August 2012 
Lateral cephalometric analysis has been extensively used for the evaluation of craniofacial features and airway soft tissue characteristics in patients with obstructive sleep apnea syndrome (OSAS) ${ }^{1-4}$. OSAS is characterized by repeated episodes of breathing cessation during sleep resulting from the obstruction of the upper airways, which collapse at distinct levels ranging from the nasal fossae to the lower portion of the hypopharynx ${ }^{1}$.

The prevalence of OSAS in children is estimated to be approximately $2 \%^{5}$, and the most common etiological factor is tonsillar and adenoid hypertrophy ${ }^{5,6}$. This condition impairs the adequate use of the nose and nasopharyngeal tract for breathing, and respiration is switched to the oral route, leading to postural adaptations of the head and neck structures ${ }^{7}$ that have an effect on craniofacial growth and on the relationship between the maxilla and mandible, with the consequent installation of dental malocclusion ${ }^{8,9}$, which include cross-bite, a narrow and deep palate, a tendency toward open bite and lip hypotonia 9 . Clinical signs are symptoms of behavioral disorders, especially alterations in cognitive functions ${ }^{10,11}$, features also observed in children with OSAS, in addition to poor growth ${ }^{12}$.

The association between craniofacial anomalies and respiratory sleep disorders, such as snoring and OSAS, has been confirmed in several studies ${ }^{13,14}$. Lowe et al. ${ }^{1}$ and Guilleminault et al. ${ }^{4}$ documented changes that occur in the craniofacial structures of patients with OSAS using lateral cephalometric radiography. Apneic patients show retruded mandible, greater inclination of the occlusal and mandibular planes, and reduced nasopharyngeal and posterior airway space $^{4}$ that we called apneic pattern ${ }^{15,16}$. These authors also studied the abnormalities in relation to skeletal subtype ${ }^{17}$ and gender in adult patients, but not in children.

Before the age when mandibular and maxillar growth spurts begin, boys and girls have similar mean increment in the bones' face, but girls start spurting about 1.5 years earlier than boys and before menarche ${ }^{18}$. Since the mean age of children at diagnosis of OSAS is seven years ${ }^{19}$ and the condition is more common in boys ${ }^{10}$, we questioned whether facial growth is the same in boys and girls and whether mouth breathing affects both genders in a different manner. Hormones act differently on boys and girls during prepuberty and puberty in terms of both the type of hormone secreted and age $\mathrm{e}^{20}$. Besides, there are differences between the amount of growth in maxilla and mandible since the beginning of life. Children between nine and ten years are supposed to have maxilla and mandible in normal anteroposterior relationship. On age of 12 years, all craniofacial complex has achieved $90 \%$ of its total growth ${ }^{21}$, which can be assessed by cephalometric analyses ${ }^{22}$.

Our hypothesis is that girls and boys are affected differently regarding to the facial growth in relation to mode of breathing. Thus, the objective of the present study was to compare cephalometric measures between oral breathers, so called mouth-breathers, boys and girls to nose-breather ones, and to compare the results obtained from both with the cephalometric OSAS pattern.

\section{METHODS}

\section{Participants}

The study was conducted on 145 children aged 7 to 14 years recruited from two Pastoral Community Centers, São Paulo city, Brazil. Children who underwent surgical treatment of the oral cavity and/or structures related to the nasopharyngeal air space such as tonsillectomy, adenoidectomy or adenotonsillectomy were excluded from the study. Children previously submitted to or currently undergoing orthodontic or facial orthopedic treatment, obese children or children with body mass index (BMI) greater than 25 were also excluded. A total of 144 children (52 mouth breathing children, 27 boys, and 92 nose breathing children, 60 boys, mean age boys $127 \pm 23.0$ months and mean age girls $128.6 \pm 23.8$ months) were transported to the Papaiz Associados Dental Radiology Institute, São Paulo, for the acquisition of vertical lateral cephalometric radiographs. One child did not appear on the day of the exam.

The Research Ethics Committee from UNIFESP approved the study (\#0896/03). After being informed about the objectives of the study, the children's parents or responsible persons signed an informed consent form and an authorization for transport of the children to the Radiology Institute for cephalometric radiography as requested by the Ethics Committee.

\section{Assessment}

\section{Clinical assessment}

To classify children as nasal or mouth breathers, a medical ear, nose and throat evaluation was carried out including nasofibroscopy (MACHIDA, Japan) looking for the presence of upper airway obstruction by hypertrophic tonsils, adenoids or rhinitis.

We adopted a classification of Cassano et al. ${ }^{23}$ for adenoid hypertrophy, and a significant hypertrophy was considered when $75 \%$ or more obstruction was detected in the airway through the nasofibroscopy evaluation. The same approach was adopted when evaluating nasal concha and tonsils. To be classified as mouth breather, the child should complete all the following criteria: parents report that the child breathes through the mouth, sleeps with the mouth opened, dribbles on the pillow three times a week or more and showed adenoidal obstruction in the nasofibroscopy evaluation. A child was classified as nasal breather when the parents did not report any complaint as mentioned above and also the child did not show any significant obstruction in the nasofibroscopy. We took in account only loud and continuous snore as complementary information to classify a child as mouth breather, because this kind of information is variable and subjected 
to individual sensitivity and degree of attention toward the child. All children underwent to an orthodontic evaluation (data not showed in this study) and they were subjected to lateral teleradiography to obtain cephalometric tracings.

\section{Lateral cephalometric radiography}

Lateral cephalometric radiographs (Fig 1) were obtained with the children sitting on a chair in the upright position, with the teeth in natural occlusion. A cephalostat was used to keep the subject with the Frankfurt plane parallel to the floor. Before radiography, the children rinsed their mouth and swallowed $10 \mathrm{~mL}$ of barium sulfate for visualization of soft structures such as the tongue, soft palate, epiglottis and posterior region of the pharynx. Radiographs were taken with an EMIC model MKT 100 X-ray apparatus, maintaining a distance of $152 \mathrm{~cm}$ between the X-ray emission point and the center of the cephalostat.

\section{Cephalometric measurements}

The radiographs were directly handed over to the responsible person in the secretarial office of the research center who blinded their identification with opaque labels. The radiographs were then stored in randomly numbered envelopes. After collection of population data, one of the authors (MLJ), who was unaware to whom the radiographs belonged, traced the radiographs on Ultraphan paper placed on a negatoscope. An anatomical drawing was obtained and the lines and planes were traced (Fig 2) for the determination of the cephalometric variables in Table 1.

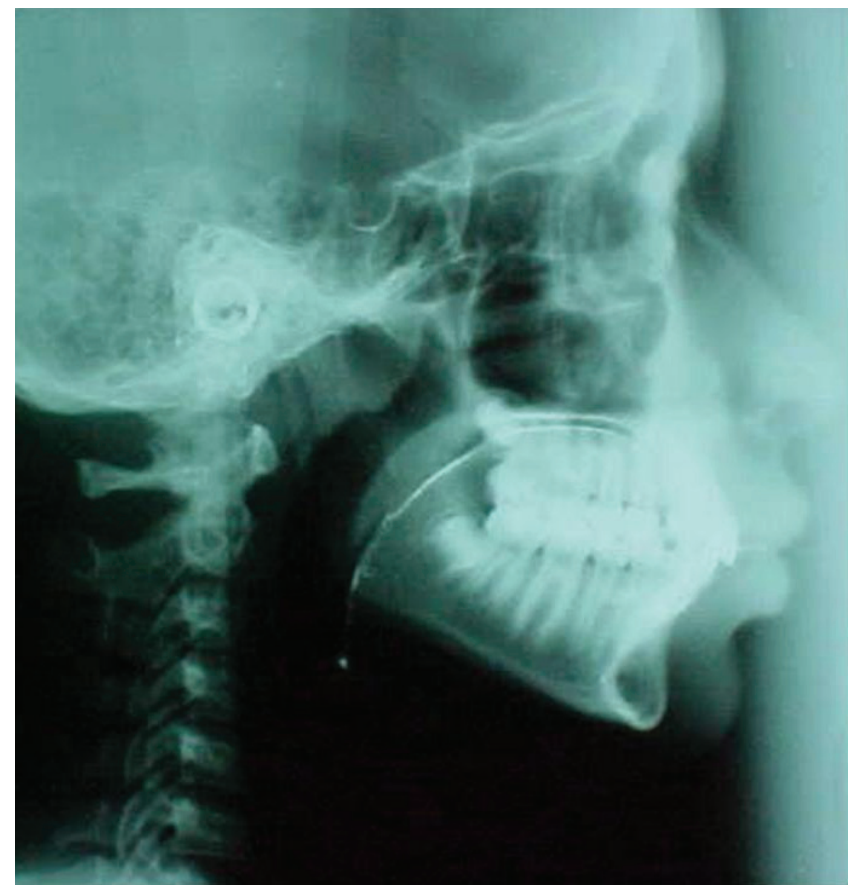

Fig 1. Lateral cephalometric radiography.

\section{Data analysis}

The results of the variables obtained for each child were stored in an electronic spreadsheet (Microsoft Excel) ${ }^{\circledR}$. Next, the labels covering the identification of children regarding mouth breathing, nose breathing and gender were removed, and the groups were regrouped as follows: mouth breathing boys and girls, nose breathing boys and girls, mouth and nose breathing girls, and mouth and nose breathing boys.

Since the data showed a Gaussian distribution, the mean and standard deviation were calculated for each variable. The cephalometric measurements obtained from mouth and nose breathing boys and girls were compared by the Student $t$-test and ANOVA. We used the logistic regression to verify the effects of interaction between the cephalometric variables and mouth/nose breathing children. We used the chi-square test to compare the percentage of mouth/nose breathing boys and girls with the cephalometric pattern of OSAS, which has been widely described in the literature ${ }^{1-4,13,26}, \mathrm{p}<0.05$ was considered significant.

\section{RESULTS}

\section{Groups of nose-breather boys and girls}

We observed in boys (Table 2), a greater difference in the anteroposterior position between maxilla and mandible (ANB; $\mathrm{p}=0.05$ ), a trend to a more retruded mandible (SNB; $\mathrm{p}=0.07$ ), and a proinclined upper incisor (1-NA; $\mathrm{p}=0.06)$. There was no significant difference in the amount of boys and girls with cephalometric pattern of OSAS (Table 3).

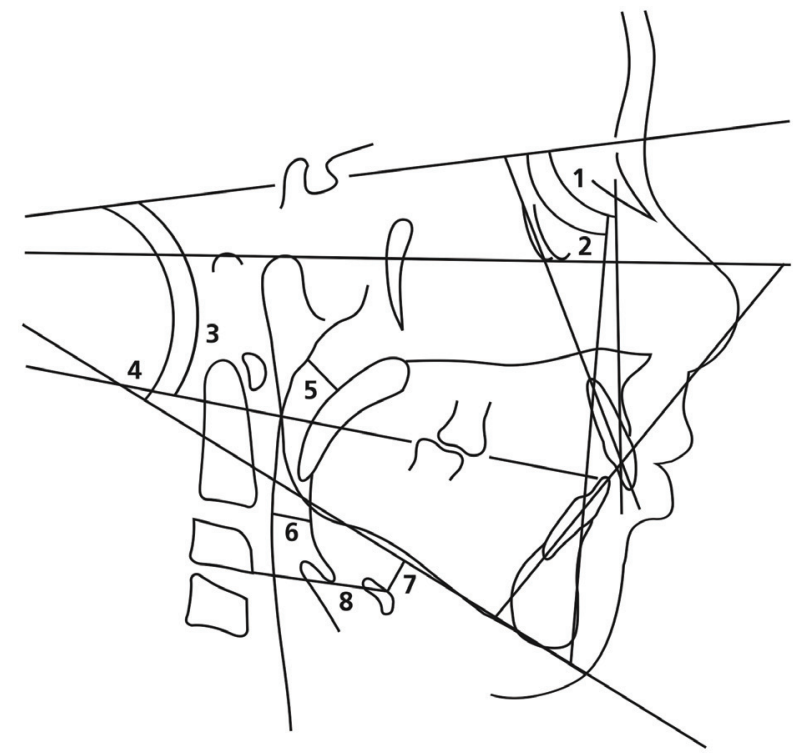

$1=$ SNA; $2=S N B ; 3=N S . P I 0 ; 4=N S . G o G n ; 5=S P A S ; 6=P A S ; 7=M P H ; 8=C_{3}-\mathrm{H}$.

Fig 2. Anatomical drawing showed linear measurements and angles traced for the determination of the cephalometric variables. 


\section{Groups of mouth-breather boys and girls}

The cephalometric measures were similar in the two groups (Table 2), with no significant differences in maxillomandibular variables, inclination of the occlusal plane (NS. $\mathrm{PlO}$ ), inclination of the mandibular plane (NS.GoGn), position of the incisors (1.NA, 1-NA, 1.NB e 1-NB), PAS, or position of the hyoid bone (MP-H and $\left.\mathrm{C}_{3}-\mathrm{H}\right)$. The proportion of boys and girls with the pattern of OSAS was similar (Table 3).

\section{Groups of mouth and nose-breather boys}

Mouth-breather boys tended to present a more retruded maxilla $(\mathrm{p}=0.08)$, greater inclination of the occlusal and mandibular planes $(\mathrm{p}=0.001)$, greater inclination of the upper incisor $(\mathrm{p}=0.05)$ and reduced nasopharyngeal airway space $(\mathrm{p}=0.001)$ and PAS $(\mathrm{p}<0.05)$ compared to nose-breather boys (Table 2). In comparison to the apneic pattern, higher than normal values were obtained

Tabela 1. Cephalometric variables used in this study.

\begin{tabular}{|c|c|c|c|}
\hline Variable & Description & Measure indicates the & Normal value \\
\hline SNA & Angle formed by the sella-nasion line and line $\mathrm{N}$-point $\mathrm{A}$ & $\begin{array}{l}\text { anteroposterior position of the maxilla } \\
\text { in relation to the skull base }\end{array}$ & $82^{\circ}$ \\
\hline SNB & Angle formed by the sella-nasion line and line $\mathrm{N}$-point $\mathrm{B}$ & $\begin{array}{l}\text { anteroposterior position of the } \\
\text { mandible in relation to the skull base }\end{array}$ & $80^{\circ}$ \\
\hline ANB & Differences between the SNA and SNB angles & relation between maxilla and mandible & $2^{\circ}$ \\
\hline NS.PIO & Angle formed by the sella-nasion line and the occlusal plane & $\begin{array}{l}\text { inclination of the occlusal plane in } \\
\text { relation to the skull base }\end{array}$ & $14^{\circ}$ \\
\hline NS.GoGn & Angle formed by the sella-nasion line and mandibular plane & $\begin{array}{l}\text { inclination of the mandibular plane in } \\
\text { relation to the skull base }\end{array}$ & $36^{\circ}$ \\
\hline 1.NA & Angle of inclination of the upper incisor in relation to the NA line & $\begin{array}{l}\text { extent of anterior inclination of the } \\
\text { upper incisor }\end{array}$ & $22^{\circ}$ \\
\hline $1-N A$ & $\begin{array}{l}\text { Linear distance between the most salient point of the buccal side of the } \\
\text { upper incisor and the NA line measured perpendicularly to the latter }\end{array}$ & $\begin{array}{l}\text { extent of anterior inclination of the } \\
\text { upper incisor }\end{array}$ & $4 \mathrm{~mm}$ \\
\hline 1.NB & $\begin{array}{l}\text { Angle of inclination of the lower incisor in relation to the NB line, which } \\
\text { determines the extent of anterior inclination of the lower incisor }\end{array}$ & $\begin{array}{l}\text { extent of anterior inclination of the } \\
\text { lower incisor }\end{array}$ & $25^{\circ}$ \\
\hline $1-N B$ & $\begin{array}{l}\text { Linear distance between the most salient point of the buccal side of the } \\
\text { lower incisor and the NB line measured perpendicularly to the latter }\end{array}$ & $\begin{array}{l}\text { extent of anterior inclination of the } \\
\text { lower incisor }\end{array}$ & $4 \mathrm{~mm}$ \\
\hline SPAS & $\begin{array}{l}\text { the thickness of the airway behind the soft palate along a line parallel } \\
\text { to the Go-B point plane }{ }^{24}\end{array}$ & $\begin{array}{l}\text { obstruction of superior posterior } \\
\text { airway space }\end{array}$ & $10 \mathrm{~mm}$ \\
\hline PAS & $\begin{array}{l}\text { Linear distance between a point at the base of the tongue and another } \\
\text { point on the posterior wall of the pharynx, both measured by the } \\
\text { extension of a line from point B to point } \mathrm{Go}^{4}\end{array}$ & obstruction of posterior airway space & $10 \mathrm{~mm}$ \\
\hline $\mathrm{MP}-\mathrm{H}$ & $\begin{array}{l}\text { Linear distance between } \mathrm{H} \text {, the most anterosuperior point of the hyoid } \\
\text { bone, and the mandibular plane measured perpendicularly to the latter }{ }^{25}\end{array}$ & $\begin{array}{l}\text { risk of occlusion, that increases } \\
\text { directly with the distance }\end{array}$ & $18 \mathrm{~mm}$ \\
\hline $\mathrm{C} 3-\mathrm{H}$ & $\begin{array}{l}\text { Linear distance between } \mathrm{C}_{3} \text { and } \mathrm{H} \text {, where } \mathrm{C}_{3} \text { is the most anteroinferior } \\
\text { point of the third cervical vertebra }\end{array}$ & $\begin{array}{l}\text { risk of occlusion, that increases } \\
\text { inversely with the distance }\end{array}$ & $35 \mathrm{~mm}$ \\
\hline
\end{tabular}

Table 2. Cephalometric measures (means ( \pm ) standard deviation) of nose and mouth-breather boys and girls.

\begin{tabular}{|c|c|c|c|c|c|c|c|c|}
\hline \multirow{2}{*}{$\begin{array}{l}\text { Cephalometric } \\
\text { measures }\end{array}$} & \multicolumn{2}{|c|}{ Nose-breather } & \multicolumn{2}{|c|}{ Mouth-breather } & \multicolumn{2}{|c|}{ Boys } & \multicolumn{2}{|c|}{ Girls } \\
\hline & $\begin{array}{l}\text { Boys } \\
n=58\end{array}$ & $\begin{array}{l}\text { Girls } \\
n=31\end{array}$ & $\begin{array}{l}\text { Boys } \\
n=27\end{array}$ & $\begin{array}{l}\text { Girls } \\
\mathrm{n}=25\end{array}$ & $\begin{array}{l}\text { Nose- } \\
\text { breather }\end{array}$ & $\begin{array}{l}\text { Mouth- } \\
\text { breather }\end{array}$ & $\begin{array}{l}\text { Nose- } \\
\text { breather }\end{array}$ & $\begin{array}{l}\text { Mouth- } \\
\text { breather }\end{array}$ \\
\hline $\mathrm{SNA}^{\circ}$ & $83.7 \pm 4.1$ & $84.8 \pm 4.0$ & $82.1 \pm 3.8$ & $83.0 \pm 3.8$ & $83.7 \pm 4.1$ & $82.1 \pm 3.8^{\dagger}$ & $84.8 \pm 4.0$ & $83.0 \pm 3.8$ \\
\hline $\mathrm{SNB}^{\circ}$ & $78.7 \pm 4.1$ & $80.8 \pm 4.1^{\dagger}$ & $77.1 \pm 3.6$ & $77.8 \pm 3.6$ & $78.7 \pm 4.1$ & $77.1 \pm 3.6$ & $80.8 \pm 4.1$ & $77.8 \pm 3.6 *$ \\
\hline $\mathrm{ANB}^{\circ}$ & $4.9 \pm 2.0$ & $4.1 \pm 1.8^{*}$ & $4.9 \pm 2.3$ & $5.3 \pm 2.3$ & $4.9 \pm 2.0$ & $4.9 \pm 2.3$ & $4.1 \pm 1.8$ & $5.3 \pm 2.3^{\star}$ \\
\hline NS.PIO ${ }^{\circ}$ & $18.4 \pm 4.2$ & $17.4 \pm 4.9$ & $21.3 \pm 3.6$ & $20.8 \pm 3.8$ & $18.4 \pm 4.2$ & $21.3 \pm 3.6^{* *}$ & $17.4 \pm 4.9$ & $20.8 \pm 3.8 * *$ \\
\hline NS.GoGnº & $34.3 \pm 5.5$ & $32.1 \pm 6.3$ & $38.0 \pm 4.6$ & $38.5 \pm 6.0$ & $34.3 \pm 5.5$ & $38.0 \pm 4.6 * *$ & $32.1 \pm 6.3$ & $38.5 \pm 6.0 * *$ \\
\hline 1.NA ${ }^{\circ}$ & $23.7 \pm 5.7$ & $24.1 \pm 6.3$ & $27.3 \pm 5.4$ & $25.3 \pm 7.0$ & $23.7 \pm 5.7$ & $27.3 \pm 5.4^{\star \star}$ & $24.1 \pm 6.3$ & $25.3 \pm 7.0$ \\
\hline 1-NA mm & $4.7 \pm 2.0$ & $4.1 \pm 1.6^{+}$ & $5.7 \pm 2.0$ & $4.8 \pm 2.6$ & $4.7 \pm 2.0$ & $5.7 \pm 2.0 *$ & $4.1 \pm 1.6$ & $4.8 \pm 2.6$ \\
\hline 1. $\mathrm{NB}^{\circ}$ & $30.9 \pm 5.7$ & $31.1 \pm 5.1$ & $33.0 \pm 6.1$ & $30.4 \pm 5.1$ & $30.9 \pm 5.7$ & $33.0 \pm 6.1$ & $31.1 \pm 5.1$ & $30.4 \pm 5.1$ \\
\hline 1-NB mm & $6.6 \pm 2.4$ & $6.2 \pm 2.1$ & $7.7 \pm 3.0$ & $7.2 \pm 2.6$ & $6.6 \pm 2.4$ & $7.7 \pm 3.0^{\dagger}$ & $6.2 \pm 2.1$ & $7.2 \pm 2.6$ \\
\hline SPAS mm & $10.4 \pm 3.1$ & $9.8 \pm 2.2$ & $4.6 \pm 2.0$ & $5.2 \pm 1.7$ & $10.4 \pm 3.1$ & $4.6 \pm 2.0 * \star$ & $9.8 \pm 2.2$ & $5.2 \pm 1.7 * \star$ \\
\hline PAS mm & $12.6 \pm 3.3$ & $11.8 \pm 2.8$ & $9.7 \pm 3.6$ & $10.5 \pm 2.4$ & $12.6 \pm 3.3$ & $9.7 \pm 3.6 * \star$ & $11.8 \pm 2.8$ & $10.5 \pm 2.4^{\dagger}$ \\
\hline MP-H mm & $10.9 \pm 5.0$ & $12.4 \pm 5.1$ & $12.1 \pm 4.7$ & $11.5 \pm 6.0$ & $10.9 \pm 5.0$ & $12.1 \pm 4.7$ & $12.4 \pm 5.1$ & $11.5 \pm 6.0$ \\
\hline $\mathrm{C}_{3}-\mathrm{H} \mathrm{mm}$ & $34.7 \pm 3.4$ & $35.1 \pm 3.4$ & $33.4 \pm 2.6$ & $33.8 \pm 3.8$ & $34.7 \pm 3.4$ & $33.4 \pm 2.6^{*}$ & $35.1 \pm 3.4$ & $33.8 \pm 3.8$ \\
\hline
\end{tabular}

${ }^{\dagger} p<0.10 ;{ }^{*} p<0.05 ;{ }^{* *} p<0.01$ 
for NS.PlO (inclination of the occlusal plane, $\mathrm{p}<0.05$ ) and NS.GoGn (inclination of the mandibular plane, $\mathrm{p}<0.01$ ), and lower than normal values were obtained for nasopharyngeal airway space $($ SPAS, $p<0.01)$ and PAS $(\mathrm{p}<0.05)$ in mouth-breather boys (Table 3 ). The vertebra-to-hyoid distance $\left(\mathrm{C}_{3}-\mathrm{H}\right)$ was larger in mouth-breather boys than in nose-breather ones $(\mathrm{p}<0.05)$, but the hyoid bone-to-mandibular plane distance (MP-H) did not differ between the two groups (Table 2). Comparison of these distances with the cephalometric pattern observed in patients with OSAS showed a greater proportion of oral breathing boys, having a tendency to present a smaller distance hyoid bone-to- $\mathrm{C}_{3}$ vertebrae, but no significant difference in the position of the hyoid bone in relation to mandibular plane was observed (Table 3).

\section{Groups of mouth and nose-breather girls}

Mouth-breather girls presented a more retruded mandible (SNB and ANB, $\mathrm{p}<0.05$ ), as well as greater inclination of the occlusal and mandibular planes (NS.PlO and NS.GoGn, $\mathrm{p}<0.01$ ), and a reduced nasopharyngeal airway space $(\mathrm{p}<0.0001)$ and PAS $(\mathrm{p}=0.07)$ compared to nosebreather girls (Table 2). Comparison of the two groups with the cephalometric pattern of OSAS revealed an ANB angle (anteroposterior angular difference between the maxilla and mandible) compatible with the apneic pattern in the group of mouth-breather girls $(\mathrm{p}<0.05)$; this group also presented a greater amount of children with more inclination of the occlusal $(p=0.06)$ and mandibular planes $(p<0.01)$, and a smaller nasopharyngeal airway space $(\mathrm{p}<0.01)$ when compared to the OSAS pattern (Table 3).

The logistic regression model adjusted to the groups (mouth and nose breathing) showed that NS.GoGn was the only predictive variable of the pattern observed in patients with OSAS and it had an interaction with gender (Table 4). The odds of a mouth breathing girl to present a higher value of NS.GoGn was 4.02 times the odds of a mouth breathing boy to present increased NS.GoGn measure.

\section{DISCUSSION}

This study showed the expected cephalometric difference between nose-breather boys and girls, and when they are mouth-breathers such differences disappear, meaning that the difference growing acceleration between them does not occur in the facial complex. The study also showed that mouth-breather children presented cephalometric

Table 3. Percentage of nose and mouth-breather boys and girls that presented cephalometric of adult patients with obstructive sleep apnea syndrome.

\begin{tabular}{|c|c|c|c|c|c|c|c|c|c|}
\hline \multirow{2}{*}{\multicolumn{2}{|c|}{ Apneic pattern }} & \multicolumn{2}{|c|}{ Nose-breather } & \multicolumn{2}{|c|}{ Mouth-breather } & \multicolumn{2}{|c|}{ Boys } & \multicolumn{2}{|c|}{ Girls } \\
\hline & & \multirow{2}{*}{$\begin{array}{c}\text { Boys } \\
n=58\end{array}$} & \multirow{2}{*}{$\begin{array}{c}\text { Girls } \\
n=31\end{array}$} & \multirow{2}{*}{$\begin{array}{c}\text { Boys } \\
n=27\end{array}$} & \multirow{2}{*}{$\begin{array}{c}\text { Girls } \\
n=25\end{array}$} & \multirow{2}{*}{$\begin{array}{c}\begin{array}{c}\text { Nose- } \\
\text { breather }\end{array} \\
27\end{array}$} & \multirow{2}{*}{$\begin{array}{c}\text { Mouth- } \\
\text { breather } \\
44\end{array}$} & \multirow{2}{*}{$\begin{array}{c}\begin{array}{c}\text { Nose- } \\
\text { breather }\end{array} \\
26\end{array}$} & \multirow{2}{*}{$\begin{array}{c}\text { Mouth- } \\
\text { breather } \\
32\end{array}$} \\
\hline $\mathrm{SNA}^{\circ}$ & $<81.84^{\circ}$ & & & & & & & & \\
\hline $\mathrm{SNB}^{\circ}$ & $<78.74^{\circ}$ & 46 & 42 & 67 & 56 & 46 & 67 & 42 & 56 \\
\hline $\mathrm{ANB}^{\circ}$ & $>4^{\circ}$ & 59 & 39 & 55 & 72 & 59 & 55 & 39 & $72 *$ \\
\hline NS.PIO & $>14^{\circ}$ & 84 & 74 & 100 & 96 & 84 & $100 *$ & 74 & $96^{+}$ \\
\hline NS.GoGn & $>36^{\circ}$ & 32 & $13^{+}$ & 67 & 52 & 32 & $67 * \star$ & 13 & $52 * \star$ \\
\hline 1. $N A^{\circ}$ & $>22^{\circ}$ & 59 & 55 & 78 & 64 & 59 & 78 & 55 & 64 \\
\hline 1-NA mm & $>4 \mathrm{~mm}$ & 50 & $29^{+}$ & 63 & 48 & 50 & 63 & 29 & 48 \\
\hline 1. $\mathrm{NB}^{\circ}$ & $>25^{\circ}$ & 86 & 90 & 89 & 80 & 86 & 89 & 90 & 80 \\
\hline 1-NB mm & $>4 \mathrm{~mm}$ & 79 & 81 & 89 & 88 & 79 & 89 & 81 & 88 \\
\hline SPAS $^{\circ}$ & $<8 \mathrm{~mm}$ & 17 & 16 & 93 & 92 & 17 & $93 * *$ & 16 & $92 * \star$ \\
\hline PAS mm & $<11.88 \mathrm{~mm}$ & 33 & 42 & 63 & 56 & 33 & $63^{*}$ & 42 & 56 \\
\hline $\mathrm{MP}-\mathrm{H} \mathrm{mm}$ & $>17.75 \mathrm{~mm}$ & 12 & 13 & 11 & 12 & 12 & 11 & 13 & 12 \\
\hline $\mathrm{C}_{3}-\mathrm{H} \mathrm{mm}$ & $<34.66 \mathrm{~mm}$ & 39 & 35 & 63 & 56 & 46 & $63^{+}$ & 35 & 56 \\
\hline
\end{tabular}

${ }^{\dagger} p<0.10 ;{ }^{*} p<0.05 ;{ }^{*} p<0.01$

Table 4. Logistic regression for the cephalometric variable NS. GoGn by mouth/nose-breather boys and girls.

\begin{tabular}{lcccccc} 
& $\begin{array}{c}\text { Value in the } \\
\text { equation }\end{array}$ & $\begin{array}{c}\text { Standard } \\
\text { error }\end{array}$ & $\begin{array}{c}\text { Wald Test for } \\
\text { final model }\end{array}$ & $\begin{array}{c}\text { Degrees of } \\
\text { freedom }\end{array}$ & Significance & Exponential base \\
\hline Mouth breathing & 1.671 & 0.395 & 17.887 & 1 & $<0.001$ & 5.318 \\
Gender: girls & -0.891 & 0.406 & 4.823 & 1 & 0.028 & 0.410 \\
Constant & -0.835 & 0.264 & 10.022 & 1 & 0.001 & 0.434 \\
\hline
\end{tabular}


pattern similar to the one reported in literature for adults patients with OSAS ${ }^{1-4,13}$.

No measurements compatible with the pattern of adult patients with OSAS were observed in nose-breather girls, but nose-breather boys showed a tendency to have lower SNB and ANB angles, which means a more retruded mandible, and they tended to have proinclined upper incisors (1-NA) when they were compared to girls. These findings were expected because girls develop earlier than boys.

This is the first study demonstrating that oral breather boys and girls did not show the expected differences related to mandible development, suggesting that the disordered breathing make them equal aborting the expected gender differences in the craniofacial growth.

The growth pattern of boys and girls diverges after ten years of age. In the first phase of pubertal growth, the growth spurt occurs between 13 and 15 years of bone age in boys and between 11 and 13 years in girls ${ }^{27}$. In girls, growth starts to slow down after menarche, which generally occurs between 13 and 13.5 years of bone age, when growth acceleration is starting in boys ${ }^{27}$.

In contrast to girls, mouth-breather boys presented the hyoid bone-to- $\mathrm{C}_{3}$ vertebra $\left(\mathrm{C}_{3}-\mathrm{H}\right)$ distance reduced when they were compared to nose-breather boys, and the hyoid bone-to-mandibular plane distance was increased, what was also observed in the cephalometric pattern of adult patients with OSAS. Mouth and nose-breather girls did not have these differences, and we think that it happens because the hyoid bone occupies a more anterior position in mouth-breather boys ${ }^{28,29}$. Under normal conditions, the distance between the hyoid bone and cervical vertebra remains constant until puberty when the hyoid bone moves slightly forward ${ }^{3}$. Mouth breathing causes postural alterations with a consequent change in the position of the hyoid bone, a fact that might explain the alterations in this parameter observed in mouth-breather boys. In the present study, the $\mathrm{C}_{3}-\mathrm{H}$ measurement was increased in mouthbreather children; to improve their respiratory pattern, these patients extend the head, thus increasing cervical kyphosis ${ }^{7}$ and also the $\mathrm{C}_{3}-\mathrm{H}$ distance.

In conclusion, the present study demonstrated that there are no differences between cephalometric pattern of mouth-breather boys and girls as observed for nosebreather ones. A greater amount of mouth-breather children presented the cephalometric parameters of adult patients with OSAS, suggesting that this abnormal craniofacial morphology develops very early in the clinical history of patients with OSAS. Moreover, because girls reach growth stages earlier than boys, we should pay more attention to the diagnosis and treatment of oral-breather girls, mostly if we are attempting to perform some orthopedic approach ${ }^{30}$, when they have to be treated earlier to take advantage of the physiologic period of accelerated maxillomandibular growth.

\section{References}

1. Lowe AA, Santamaria JD, Fleetham JA, Price C. Facial morphology and obstructive sleep apnea. Am J Orthod Dentofac Orthop 1986;90:484-491.

2. Lyberg $T$, Krogstad O, Djupeslandi G. Cephalometric analysis in patients with obstructive sleep apnoea syndrome. I. Skeletal morphology. J Laryngol Otol 1989;103:287-292.

3. Guilleminault C, Riley R, Powell N. Obstructive sleep apnea and abnormal cephalometric measurements. Chest 1984;86:793-794.

4. Guilleminault C, Partinen M, Praud JP, Quera-Salva MA, Powell N, Riley R. Morphometric facial changes and obstructive sleep apnea in adolescents. J Pediatr 1989;114:997-999.

5. Marcus CL. Obstructive sleep apnea syndrome: differences between children and adults. Sleep 2000;23(:S140-S141.

6. Arens R, Marcus CL. Pathophysiology of upper airway obstruction: a development perspective. Sleep 2004;27:997-1019.

7. Huggare JA, Laine-Alava T. Nasorespiratory function and head posture. Am J Orthod Dentofac Orthop 1997;12:507-511.

8. Kawashima S, Peltomäki T, Sakata H, Mori K, Happonen R-P, Rönning O. Craniofacial morphology in preschool children with sleep-related breathing disorder and hypertrophy of tonsils. Acta Paediatr 2002;91:71-77

9. Caprioglio A, Zucconi M, Calori G, Troiani V. Habitual snoring OSA and craniofacial modification. Orthodontic and diagnostic aspects in a case control study. Minerva Stomatol 1999;48:125-137.
10. Guilleminault C, Korobkin R, Winkle R. A review of 50 children with obstructive sleep apnea syndrome. Lung 1981;159:275-287.

11. Carvalho LBC, Prado LBF, Silva L, et al. Cognitive dysfunction in children with sleep-disordered breathing. J Child Neurol 2005;20:400-404.

12. Marcus CL, Carroll JL, Koerner CB, Hamer A, Lutz J, Loughlin GM. Determinants of growth in children with the obstructive sleep apnea syndrome. J Pediatr 1994;125:556-562.

13. Miyao E, Miyao M, Ohta T, et al. Differential diagnosis of obstructive sleep apnea syndrome patients and snorers using cephalograms. Psychiatry Clin Neurosci 2000;54:659-664.

14. Zucconi M, Caprioglio A, Calori G, et al. Craniofacial modifications in children with habitual snoring and obstructive sleep apnoea: a casecontrol study. Eur Respir J 1999;13:411-417.

15. Juliano ML, Machado MC, Carvalho LBC, Prado LB, Prado GF Craniofacial morphology of oral breathing children relates to obstructive sleep apnea cephalometric pattern. Sleep 2005;28:A91.

16. Juliano ML, Machado MC, Carvalho LBC, Prado LB, Prado GF. Mouth breathing children have cephalometric patterns similar to those of adult patients with obstructive sleep apnea syndrome. Arq Neuropsiquiatr 2009;67:860-865.

17. Lowe AA, Ono T, Ferguson KA, Pae EK, Ryan CF, Fleetham JA. Cephalometric comparisons of craniofacial and upper airway structure by skeletal and gender in obstructive sleep apnea. Am J Orthod Dentofacial Orthop 1996;110:653-664. 
18. Lewis A, Roche AF, Wagner B. Growth of the mandible during pubescence. Angle Orthod 1982;52:325-342.

19. Peltomäki T. The effect of mode of breathing on craniofacial growthrevisited. Eur J Orthod 2007;29:426-429.

20. Waal HAD, Coeverden SCCM, Rotteveel J. Hormonal determinants of pubertal growth. J Pediatr Endocrinol Metab 2001;14:1521-1526.

21. Aydemir S, Çeylan I, Eröz ÜB. Longitudinal cephalometric changes in the maxilla, mandible and maxillary-mandibular relationship between 10 and 14 years of age. Aust Orthod J 1999;15:284-288.

22. Chang HP. Assessment of anteroposterior jaw relationship. Am J Orthod Dentofacial Orthop 1987;92:117-122.

23. Cassano P, Gelardi M, Cassano M, Fiorella ML, Fiorella R. Adenoid tissue therapeutic management. Int J Pediatr Otorhinolaryngol 2003;67:1303-1309.

24. Kikuchi M, Higurachi N, Miyazaki S, Itasaka Y. Facial patterns of obstructive sleep apnea patients using Ricketts' method. Psychiatry Clin Neurosci 2000;54:336-337.
25. Bibby RE, Preston CB. The hyoid triangle. Am J Orthod 1981;80:92-97.

26. Miles PG, Vig PS, Weyant RJ, Forrest TD, Rochette Jr HE. Craniofacial structure and obstructive sleep apnea syndrome - a qualitative analysis and meta-analysis of the literature. Am J Orthod Dentofacial Orthop 1996;109:163-172.

27. Miklashevskaya NN. Sex differences in growth of the head and face in children and adolescents. Hum Biol 1969;41:250-262.

28. Kumar R, Sidhu SS, Kharbanda OP, Tandon DA. Hyoid bone and atlas vertebra in established mouth breathers: a cephalometric study. J Clin Pediatr Dent 1995;19:191-194.

29. Kawashima S. Sex-dependent differences in craniofacial morphology of children with a sleep-related breathing disorder. Oral Surg Oral Med Oral Pathol Oral Radiol Endod 2002;94:167-174.

30. Villa MP, Bernkopf E, Pagani J, Broia V, Montesano M, Ronchetti R. Randomized controlled study of oral jaw-positioning appliance for the treatment of obstructive sleep apnea in children with malocclusion. Am J Respir Crit Care Med 2002;165:123-127. 